\title{
A Glomerella Species Phylogenetically Related to Colletotrichum Acutatum on Norway Maple in Massachusetts
}

\section{Citation}

LoBuglio, Katherine F. and Donald H. Pfifster. 2008. A Glomerella species phylogenetically related to Colletotrichum acutatum on Norway Maple in Massachusetts. Mycologia 100(5): 710-715.

\section{Published Version}

http://dx.doi.org/10.3852/07-192

\section{Permanent link}

http://nrs.harvard.edu/urn-3:HUL.InstRepos:2766644

\section{Terms of Use}

This article was downloaded from Harvard University's DASH repository, and is made available under the terms and conditions applicable to Open Access Policy Articles, as set forth at http:// nrs.harvard.edu/urn-3:HUL.InstRepos:dash.current.terms-of-use\#OAP

\section{Share Your Story}

The Harvard community has made this article openly available.

Please share how this access benefits you. Submit a story.

\section{Accessibility}


Mycologia, 100(5), 2008, pp. 710-715. DOI: 10.3852/07-192

(C) 2008 by The Mycological Society of America, Lawrence, KS 66044-8897

\section{A Glomerella species phylogenetically related to Colletotrichum acutatum on Norway maple in Massachusetts}

\author{
Katherine F. LoBuglio ${ }^{1}$ \\ Donald H. Pfister \\ Harvard University Herbaria, Cambridge, Massachusetts \\ 02138
}

\begin{abstract}
A fungus isolated from Norway maple (Acer platanoides) in the Boston, Massachusetts, area was determined to be a species of Glomerella, the teleomorph of Colletotrichum acutatum. Pure cultures of the fungus were obtained from discharged ascospores from perithecia in leaf tissue. This fungus was determined to be homothallic based on the observation of perithecial development in cultures of single-spore isolates grown on minimal salts media and with sterile toothpicks. A morphological and molecular analysis was conducted to determine the taxonomic position of this fungus. Parsimony analyses of a combined nucleotide dataset of the ITS and LSU rDNA region, and of the D1-D2 LSU rDNA region, indicated that this species has phylogenetic affinities with Colletotrichum acutatum, C. acutatum f. sp. pineum, C. lupini, C. phormii and G. miyabeana. These results are significant because $C$. acutatum has not been reported on Acer platanoides. In addition the consistent presence of perithecia on leaf tissue and in culture is unusual for Colletotrichum, suggesting that the teleomorphic state is important in the life cycle of this fungus.
\end{abstract}

Key words: Acer, anamorph, Ascomycota, phylogeny, ribosomal DNA, teleomorph

\section{INTRODUCTION}

During fall 2006 leaves of Norway maple (Acer platanoides) in the Boston area exhibited symptoms of an anthracnose disease. Symptoms included irregularly shaped, brown, necrotic lesions with reddish margins. The lesions often were delimited by veins. From August to November perithecia with mature asci were found in the lesions on leaves still attached to trees and on leaves that had fallen prematurely. This study was undertaken to determine the identity and phylogenetic relationships of the fungus associated with the lesions as well as the mating system of the fungus.

\footnotetext{
Accepted for publication 16 May 2008.

${ }^{1}$ Corresponding author. E-mail: klobuglio@oeb.harvard.ed
}

\section{MATERIALS AND METHODS}

Isolation.-Symptomatic leaves were collected from $A$. platanoides trees Aug-Nov 2006 (FIG. 1a). Leaves were examined under a dissecting microscope (FIG. 1a) for the presence of perithecia (FIG. 1b). Petri plates containing malt-yeast-extract agar (MEYE, $3.0 \mathrm{~g}$ yeast extract, $3.0 \mathrm{~g}$ malt extract, $5.0 \mathrm{~g}$ peptone, $10.0 \mathrm{~g}$ glucose and $1 \mathrm{~L}_{2} \mathrm{H}$ ) medium were inverted over leaves with perithecia. Discharged ascospores were observed on the agar medium with a dissecting microscope within $1 \mathrm{~h}$ and transferred to fresh medium. Cultures were incubated at room temperature (approximately $23 \mathrm{C}$ ) and ambient light. Cultures also were established by placing surface-sterilized, symptomatic leaf pieces on MEYE media and incubating them under the conditions above. Colony morphology was observed from cultures grown on potato-dextrose agar (PDA, Difco, Becton Dickinson \& Co., Sparks, Maryland) incubated at $23 \mathrm{C}$ in the dark as well as at room temperature with ambient light.

Development and morphology of appressoria was observed examining the underside of glass cover slips that had been placed on the margin of developing cultures from which a block of agar had been removed.

Single-spore isolation. - To determine the compatibility system of this fungus single-spore isolates were established from ascospores produced in cultures obtained from maple leaf tissue. Mature perithecia were removed from a culture and placed on the inside surface of a Petri plate lid. The Petri plate was turned upside down so that the perithecia would discharge spores upward onto the surface of water agar. Isolated perithecia also were placed in Petri plates, crushed and flooded with sterile water. The water with ascospores was spread on the surface of water agar. Petri plates were examined with a compound microscope for germinating ascospores that were not in contact with other spores. Individual germinating ascospores were transferred to the surface of PDA, incubated at $23 \mathrm{C}$ with constant light from a 10-watt fluorescent bulb and examined every other day for growth.

Thirty-three single-spore isolates obtained as described above were grown on PDA and on a minimal salts medium with autoclaved flat toothpicks on the agar surface (Guerber and Correll 2001). Inoculum on the minimal salts medium was placed close to the toothpicks, which provide a surface for perithecial development (Guerber and Correll 2001). These cultures were grown at $23 \mathrm{C}$ under constant light provided by a 10 -watt fluorescent bulb and were examined every other day for perithecial development.

DNA isolation, amplification and sequencing.-Three of the five original $A$. platanoides isolates were selected for DNA isolation. The isolates were grown on sterile dialysis membrane (Bel-Art Products, Pequannock, New Jersey, No. 402990000) placed on the surface of PDA. Mycelium (equivalent to a volume of $250 \mu \mathrm{L}$ ) from each isolate was 


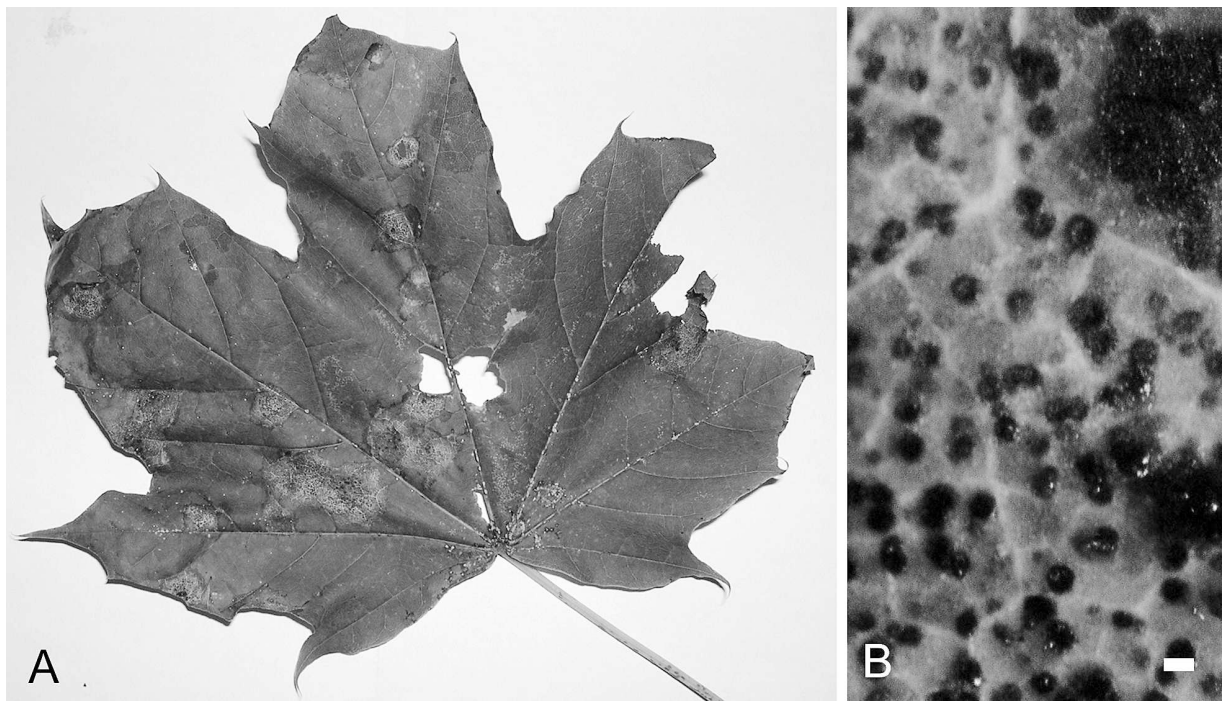

FIG. 1. Glomerella sp. on Acer platanoides. A. Irregularly shaped lesions on leaf of Acer platanoides. B. Close-up of perithecia observed on lesions. Bar $=200 \mu \mathrm{m}$.

scraped from the membrane into a $1.5 \mathrm{~mL}$ Eppendorf tube. The mycelium was ground with pestles (Kontes Glass Co., Vineland, New Jersey, No. 749521-1590) and sterile sand. A total of $500 \mu \mathrm{L}$ of SDS lysis buffer (1\% SDS; $200 \mathrm{mMTris,}$ pH 7.5; $250 \mathrm{mM} \mathrm{NaCL;} 25 \mathrm{mM}$ EDTA) was added next, followed by additional grinding. The three samples were incubated at $70 \mathrm{C}$ on a heating block with occasional grinding. This solution was extracted with phenol-chloroform and precipitated as described in Lee et al (1988). A 1/ 100 dilution of the DNA was used for PCR amplification of the ITS and LSU rDNA regions. These rDNA regions were amplified with rDNA primers ITS1 and ITS4 (White et al 1990) and LROR and LR5 (Moncalvo et al 2000). PCR amplification, purification and sequencing were carried out as described in Hansen et al (2005).

Sequence analyses.-The program Sequencher 4.6 (GeneCodes, Ann Arbor, Michigan) was used to edit nucleotide sequences. Comparison of Glomerella sequences to Colletotrichum species was done with the program Se-Al v 2.0a8 (Rambaut 1996). A total of 44 Colletotrichum sequences were compared in this analysis, 42 of which were provided by M.C. Aime (now at Louisiana State University) from a recent study of this genus (Farr et al 2006). Plectosphaerella cucumerina was chosen as the outgroup (Farr et al 2006).

Maximum parsimony analysis of the ITS-LSU combined dataset was performed with PAUP 4.0b10 (Swofford 2002). Heuristic searches consisted of 1000 random sequence addition replicates with tree bisection-reconnection branch swapping. The strength of the internal branches from the resulting trees was tested statistically by bootstrap analysis from 500 bootstrap replications.

The relationship of this fungus from maple to two species known to infect other tree hosts, C. acutatum f. sp. pineum and $G$. miyabeana, was examined by phylogenetic analysis of the D1-D2 LSU region (209 nucleotides) of taxa used in the present study and the D1-D2 LSU sequences of C. acutatum subgroups A, B and C, C. acutatum f. sp. pineum and $G$. miyabeana (EMBL No. U79691-U79700 and U79710U79713, Johnston and Jones 1997).

\section{RESULTS}

Morphology and compatibility. - Five isolates (MP1MP5) were established from either ascospores or leaf tissue. Colonies were initially white, becoming gray, green/gray, or dark gray, initially in the center but then coloring throughout. Some isolates were slightly salmon on the upper and lower surface, each with a distinct white margin. Other cultures remained white/cream to gray with or without a dark center, and some became dark olive green as viewed from the top or the under surface. Dense, elevated, aerial mycelium was characteristic of the colonies, the center often appearing green/gray velvety. Colony growth was respectively $4.5-7.8 \mathrm{~cm}$ diam after 5 and $14 \mathrm{~d}$ on PDA in the dark at 23 C. Dark structures, which resembled perithecia but did not produce asci, often were observed throughout.

Limited production of conidia was observed after $1 \mathrm{mo}$ at room temperature under ambient light. Conidia also formed in orange gelatinous masses throughout cultures more than 1 mo old. Conidia were hyaline, aseptate, narrow to broadly oblong, straight to irregular in outline, with one end tapered. Conidia were $10-25 \times 3-7 \mu \mathrm{m}$. Perithecia were produced regularly in MEYE and were single or clustered and superficially embedded in the mycelium (FIG. 2a). Mature ascospores were variable at 14.4-20 × 4-6.8 $\mu \mathrm{m}$ (FIG. 2b, c). Ascospores were hyaline, aseptate, narrowly to broadly oblong and straight to slightly curved. 

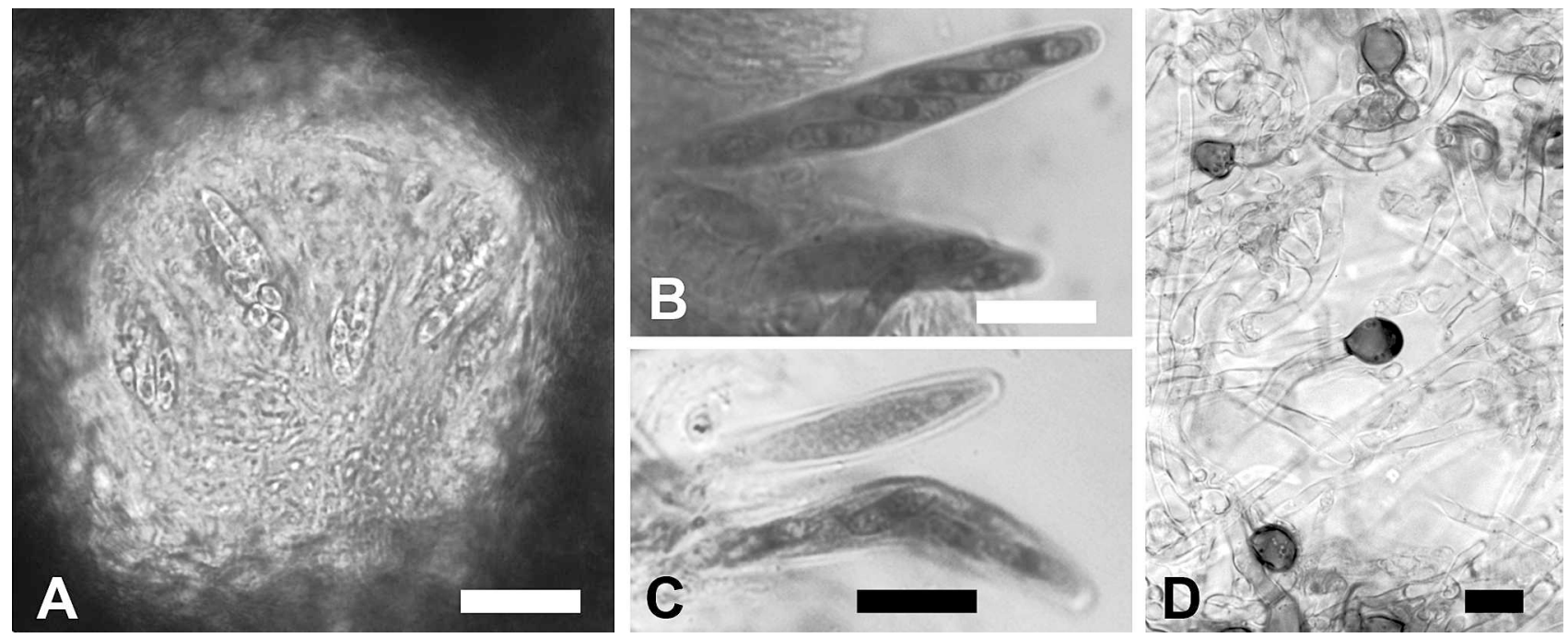

FIG. 2. Glomerella sp. from Acer platanoides. A. Longitudinal section of perithecia with asci. Bar $=50 \mu \mathrm{m}$. B. Ascus showing spore arrangement (lactophenol cotton blue). Bar $=20 \mu \mathrm{m}$. C. Young ascus. Bar $=20 \mu \mathrm{m}$. D. Appressoria produced in slide culture. Bar $=10 \mu \mathrm{m}$.

Appressoria were observed on the underside of sterile covers slips arising from vegetative hyphae (FIG. 2d). They were smooth, simple, obovate to clavate (instead of lobed and/or in chains) and varied from light to dark brown.

In all single-spore cultures perithecia containing asci with ascospores were observed after $1 \mathrm{wk}$ on inoculum plugs and on toothpicks on minimal salts medium. This observation suggests that this fungus is homothallic. Perithecia were not observed in cultures grown on PDA under the same conditions.

Phylogenetic analysis. - The ITS and LSU DNA sequences obtained for the three isolates (MP1, MP2 and MP3) were identical for both rDNA regions. The ITS-LSU dataset included 1273 nucleotide characters of which 87 were excluded due to questionable alignment. Of the remaining characters 974 were constant, 114 of the variable characters were parsimony uninformative and 98 were parsimony informative. The strict consensus of 328488 equally parsimonious trees (tree length $369, \mathrm{CI}=0.65$ and $\mathrm{RI}=0.83$ ) is provided (FIG. 3). Bootstrap values are included on branches. Our analyses showed that the fungus on maple is related phylogenetically to Colletotrichum species in the clade comprising Colletotrichum acutatum, C. lupini and C. phormii with $100 \%$ bootstrap support (FIG. 3). Phylogenetic resolution within this clade was not achieved due to the high sequence similarity among members of this group.

Phylogenetic analysis of the D1-D2 LSU rDNA region placed the fungus from maple in the $C$. acutatum clade, which included C. acutatum f. sp. pineum and G. miyabeana with $92 \%$ bootstrap support
(1000 bootstrap replications, data not shown). Phylogenetic relationships within this clade were not resolved due to the high sequence similarity among isolates (98-100\% similarity).

\section{DISCUSSION}

Molecular analyses indicated that the Glomerella species on Acer platanoides in the Boston area is phylogenetically related to species in the $C$. acutatum clade, which include $C$. acutatum, C. lupini, $C$. phormii (FIG. 3), C. acutatum f. sp. pineum and G. miyabeana. Glomerella miyabeana is a pathogen of willow and was found to be related phylogenetically to C. acutatum by Johnston and Jones (1997) using the D1-D2 LSU rDNA region. Colletotrichum acutatum has not been reported on A. platanoides, to our knowledge. Stipes and Clement (1978) reported an anthracnose on Acer platanoides in Virginia caused by Glomerella cingulata, which is considered a causal agent of anthracnose leaf spot on maple species (Sinclair and Lyons 2005). We could not find reference to G. acutata or C. acutatum as a pathogen of Acer platanoides, however C. acutatum has been reported to cause a disease of Japanese maple (Acer palmatum) in Connecticut (Smith 1993). Smith (1993) noted that perithecia never were observed on diseased plant material or in isolates from Japanese maple leaves grown either alone or in paired combinations.

Some of the morphological characters in culture of the Glomerella from Norway maple are similar to those of C. acutatum. For example the dark structures resembling perithecia that often were observed 


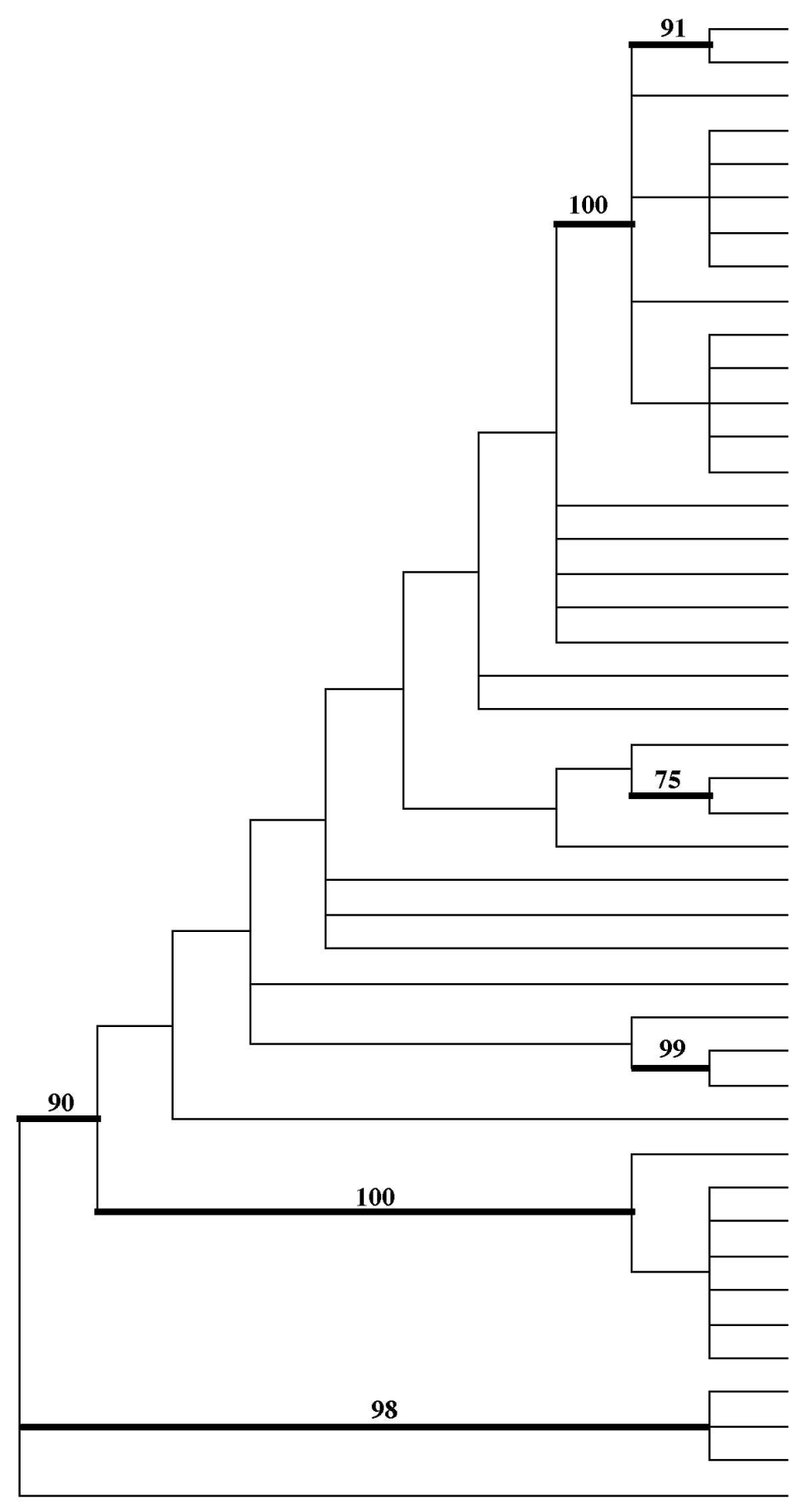

Colletotrichum lupini DQ286118/DQ286117

Colletotrichum lupini DQ286120/DQ286119

Colletotrichum acutatum DQ286133/DQ286132*

Colletotrichum acutatum DQ286122/DQ286121

Colletotrichum acutatum DQ286223/DQ286123

Colletotrichum acutatum DQ286129/DQ286128

Colletotrichum acutatum DQ286125/DQ286124

Colletotrichum acutatum DQ286127/DQ286126

Colletotrichum acutatum DQ286131/DQ286130

Glomerella Maple Isolate \#3 EU622052/EU622053

Glomerella Maple Isolate \#1

Colletotrichum phormii DQ286147/DQ286146

Colletotrichum phormii DQ286145/DQ286144

Colletotrichum phormii DQ286141/DQ286140

Colletotrichum linicola AB57437/AB106160

Colletotrichum higginsianum AB105957/AB105956

Colletotrichum glycines AB057435/AB106160

Colletotrichum fuscum AB105966/AB106161

Colletotrichum destructivum AF320562/AB106148

Colletotrichum dematium DQ286155/DQ286154

Colletotrichum dematium AJ301954

Colletotrichum trichellum DQ286153/DQ286152

Colletotrichum circinans AJ301955

Colletotrichum truncatum AJ301985

Colletotrichum coccodes AB105970/AB06153

Colletotrichum sublineolum AJ301978

Colletotrichum boninense DQ286167/DQ286166

Colletotrichum capsici DQ286159/DQ286158

Colletotrichum crassipes DQ286206/DQ286205

Colletotrichum dracaenophilum DQ286210/DQ286209

Glomerella sp. DQ286214/DQ286213

Colletotrichum sp. DQ286218/DQ286217

Colletotrichum agaves DQ286222/DQ286221

Colletotrichum gloeosporioides DQ286175/DQ286174

Glomerella cingulata DQ286201/DQ286200

Glomerella cingulata DQ286225/DQ286224

Colletotrichum gloeosporioides DQ286195/DQ286194

Glomerella cingulata DQ286181/DQ286180

Colletotrichum gloeosporioides DQ286183/DQ286182

Colletotrichum gloeosporioides DQ286189/DQ286188

Glomerella lagenerium A.J301965

Colletotrichum lindemuthianum AJ301958

Colletotrichum trifolii AJ301941

Plectosphaerella cucumerina AF176952/AF176953

FIG. 3. Strict Consensus of 328488 equally parsimonious trees based on 1186 nucleotide characters from combined ITS and LSU DNA sequences (tree length 369, CI $=0.65$ and RI $=0.83$ ). Values from 500 bootstrap replications are shown above tree branches. Asterisk indicates the type culture of Colletotrichum acutatum. Numbers after scientific names are GenBank.

throughout cultures also were observed for $C$. acutatum Group D as has been described by Lardner et al (1999). In addition few conidia were produced in culture. Production of conidia by C. acutatum has been shown to vary significantly among isolates, and loss of the ability to produce conidia in culture is not uncommon (Fernando et al 2000, Du et al 2005). Conidia were $10-25 \times 3-7 \mu \mathrm{m}$, which is longer than those reported by Simmonds (1965) in the original description of C. acutatum $(8.3-14.4 \times 2.5-4.0 \mu \mathrm{m})$ but overlaps with the morphological subgroups of $C$. acutatum described by Lardner et al (1999) and with 
C. phormii, C. acutatum f. sp. pineum and $G$. miyabeana (Farr et al 2006, Lardner et al 1999).

Many of the characters of this Glomerella differ from those of C. acutatum. These isolates lack the intense red pigment described for some isolates of $C$. acutatum (Simmonds 1965, Sutton 1992, Lardner et al 1999, Du et al 2005). Concentric rings, described in cultures for some isolates of C. acutatum (Lardner et al 1999, Du et al 2005) were not observed. Ascospores of the Glomerella from Norway maple were 14.4-20 $\times$ 4-6.8 $\mu \mathrm{m}$. This is longer than G. acutata ascospores reported from highbush blueberry $(10.0-16.3 \times 4.3-$ $5.5 \mu \mathrm{m})$ by Talgø et al (2007) and from the teleomorphs established in laboratory crosses by Guerber and Corell (2001) (12.2-17.7 × 5.0-6.5 $\mu \mathrm{m})$.

The teleomorph generally is considered to have a minor role in the life history of C. acutatum, occurring rarely if at all in nature (Bryson et al 1992, Peres et al 2005). C. acutatum typically predominates on its host in the anamorphic state producing acervuli with abundant conidia during the growing season, which are dispersed by water (Peres et al 2005, Sinclair and Lyons 2005). In the present study the teleomorph was the dominant state in the life cycle both in vivo and in vitro.

Guerber and Correll (2001) were the first to observe the teleomorph of $C$. acutatum, Glomerella acutata, from laboratory crosses of single-spore isolates. Glomerella acutata has been detected for the first time in nature on fruits from highbush blueberry (Vaccinium corymbosum) (Talgø et al 2007). The phylogenetic placement of the Glomerella from maple in the Colletotrichum acutatum clade, which includes other Glomerella species capable of producing perithecia in nature, suggests that the sexual state might have a larger role in the life history of this group than previously considered.

The fungus in this study was widespread in 2006 in eastern Massachusetts on Norway maple leaves exhibiting early defoliation in 2006. We found no evidence of this fungus on Norway maple leaves in 2007. The significantly less precipitation in Massachusetts during summer and fall 2007 compared to 2006 (www. bluehill.org) might account for the absence of this fungus on Norway maple leaves in 2007. Nonetheless no collections of this fungus could be located in the Farlow Herbarium, which house many specimens collected locally over the past $150 \mathrm{y}$.

\section{ACKNOWLEDGMENTS}

We thank Amy Y. Rossman, James C. Correll and an anonymous reviewer for helpful comments on this manuscript.

\section{LITERATURE CITED}

Bryson RJ, Caten CE, Hollomon DW, Bailey JA. 1992. Sexuality and genetics of Colletotrichum. In: Bailey JA, Jeger MJ, eds. Colletotrichum. Biology, pathology and control. Wallingford, UK: CAB International. p 27-46.

Du M, Schardl CL, Nuckles EM, Vaillancourt LJ. 2005. Using mating-type gene sequences for improved phylogenetic resolution of Colletotrichum species complexes. Mycologia 97:641-658.

Farr DF, Aime MC, Rossman AY, Palm ME. 2006. Species of Colletotrichum on Agavaceae. Mycol Res 110:1395-1408.

Fernando THP, Jayasinghe CK, Wijesundera RLC. 2000. Factors affecting spore production, germination and viability of Colletotrichum acutatum isolates from Hevea brasiliensis. Mycol Res 104:681-685.

Guerber JC, Correll JC. 2001. Characterization of Glomerella acutata, the teleomorph of Colletotrichum acutatum. Mycologia 93:216-229.

Hansen K, LoBuglio KL, Pfister DH. 2005. Evolutionary relationships of the cup-fungus genus Peziza and Pezizaceae inferred from multiple nuclear genes: RPB2, $\beta$-tublin and LSU rDNA. Mol Phylogenet Evol 36:1-23.

Johnston PR, Jones D. 1997. Relationships among Colletotrichum isolates from fruit-rots assessed using rDNA sequences. Mycologia 89:420-430.

Lardner R, Johnston PR, Plummer KM, Pearson MN. 1999. Morphological and molecular analysis of Colletotrichum acutatum sensu lato. Mycol Res 103:275-285.

Lee SB, Milgroom MG, Taylor JW. 1988. A rapid high yield mini-prep method for isolation of total genomic DNA from fungi. Fungal Genet Newslett 35:23-24.

Moncalvo J-M, Lutzoni FM, Rehner SA, Johnson J, Vilgalys R. 2000. Phylogenetic relationships of agaric fungi based on nuclear large subunit ribosomal DNA sequences. Sys Biol 49:278-305.

Peres NA, Timmer LW, Adaskaveg JE, Correll JC. 2005. Lifestyles of Colletotrichum acutatum. Plant Dis 89:784796.

Rambaut A. 1996. Se-Al. Sequence alignment editor. Version 1.0 alpha. Oxford, UK: Univ Oxford. http:// evolve.zoo.ox.ac.uk/Se-Al/Se-Al.html

Simmonds JH. 1965. A study of the species of Colletotrichum causing ripe fruit rots in Queensland. Queensland J Ag Sc 22:437-459.

Sinclair WA, Lyons HH. 2005. Diseases of trees and shrubs. 2nd ed. Ithaca, New York: Cornell Univ Press. 110 p.

Smith VL. 1993. Canker of Japanese maple caused by Colletotrichum acutatum. Plant Dis 77:197-198.

Stipes RJ, Clement GL. 1978. Anthracnose of Acer platanoides in Virginia. Virginia J Sc 29:76.

Sutton BC. 1992. The genus Glomerella and its anamorph Colletotrichum. In: Bailey JA, Jeger MJ, eds. Colletotrichum. Biology, pathology and control. Wallingford, UK: CAB International. p 1-26.

Swofford DL. 2002. PAUP*: phylogenetic analysis using parsimony (*and other methods). Version 4. Sunderland, Massachusetts: Sinauer Associates.

Talgø V, Aamot HU, Stromeng GM, Klemsdal SS, Stensvand 
A. 2007. Glomerella acutata on Highbush Blueberry (Vaccinium corymosum L.) in Norway. Plant Health Prog. DOI: 10.1094/PHP-2007-0509-01-RS.

White T, Bruns T, Lee S, Taylor J. 1990. Amplification and direct sequencing of fungal ribosomal RNA genes for phylogenetics. In: Innis MA, Gelfand DH, Sninsky JJ, White TJ, eds. PCR protocols: a guide to methods and applications. San Diego: Academic Press. p 315-322. 